\title{
Reducing taxonomic noise in problematic fossils: revision of the incertae sedis genus Allonema based on shape analysis
}

\author{
EMILIA JAROCHOWSKA, FLORIAN HIERL, OLEV VINN \& AXEL MUNNECKE
}

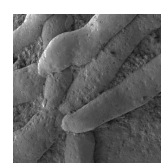

\begin{abstract}
Organisms of unknown biological affinity are widespread in Paleozoic ecosystems and play key ecological roles. Recognition of these roles relies on consistent identification and sound taxonomy, yet many microproblematica lack complex morphological features that could be the basis for qualitative taxonomic diagnoses. Allonema is an incertae sedis calcareous sclerobiont widespread in Paleozoic carbonates. At least seven species of Allonema have been proposed, but their diagnoses based on size ranges overlap. In this work, dimensions of 590 individuals from the Silurian of Estonia and Sweden have been measured. Regression analysis of the dimensions revealed two groups, overlapping in size ranges, but differing significantly in proportions. These groups could be matched with previously described A. botellus and $A$. moniliforme, but both showed a wider range of sizes than previously reported. Another previously described species, A. minimum, fell within the range of dimensions of A. moniliforme and is proposed to be its junior synonym. Differences in proportions revealed in the study do not seem to be dependent on sedimentary environment or local growth conditions such as competition for space, and thus may represent consistent interspecific variability. Although the affinity of Allonema remains unknown, this quantitative approach to its taxonomy reduces unnecessary species in the genus. The success of this approach may encourage its application to other microproblematica populating the fossil record. $\bullet$ Key words: Wetheredella, sclerobionts, pseudobryozoans, microproblematica, encrusters, Baltica, Devonian.
\end{abstract}

JAROCHOWSKA, E., HiERL, F., VinN, O. \& MUNnECKE, A. 2016. Reducing taxonomic noise in problematic fossils: revision of the incertae sedis genus Allonema based on shape analysis. Bulletin of Geosciences 91(1), 97-110 (6 figures, 4 tables, appendix). Czech Geological Survey, Prague. ISSN 1214-1119. Manuscript received September 22, 2015; accepted in revised form December 22, 2015; published online February 12, 2016; issued March 17, 2016.

Emilia Jarochowska (corresponding author), Florian Hierl \& Axel Munnecke, GeoZentrum Nordbayern, Fachgruppe Paläoumwelt, Loewenichstr. 28, 91054 Erlangen, Germany; Emilia.Jarochowska@fau.de, Florian.Hierl@fau.de, Axel.Munnecke@fau.de•Olev Vinn, Department of Geology, University of Tartu, Ravila 14A, 50411 Tartu, Estonia; Olev.Vinn@ut.ee

Organisms of uncertain biological affinity, such as acritarchs, calcitarchs, chitinozoans, or calcareous tubeworms, constitute essential parts of ecosystems in deep time (e.g. Colbath \& Grenfell 1995; Munnecke et al. 1999, 2000; Paris \& Nõlvak 1999; Malinky et al. 2004; Page et al. 2008; Vinn \& Zatoń 2012). Paleozoic carbonate environments teem with calcareous microproblematica functioning as primary producers, reef builders, and key components of carbonate factories (e.g. Riding 1991, Riding \& Soja 1993, Elicki 1999, Flügel 2004, Nose et al. 2006, Brett et al. 2012). Recognition of their affinities and ecological roles requires reliable identifications and precise communication of their occurrence and morphology. This is limited by the lack of complex features and susceptibility to taphonomic processes such as dissolution, micritization, and secondary mineralization (Pratt 1984, Berkyová \& Munnecke 2010, Jakubowicz et al. 2014).
Many problematica, such as Girvanella Nicholson \& Etheridge, 1880, Rothpletzella Wood, 1948, and Renalcis Vologdin, 1932, are extremely widespread in Paleozoic carbonates and commonly accepted as cyanobacteria, but are only described from thin sections (Wood 1948, Pratt 1984, Flügel 2004). In rare cases the growth habit and morphology can be reconstructed using three-dimensional models (Frisch et al. 2013), but isolated body fossils are almost never matched with their counterparts in thin sections. A rare exception is the Paleozoic microproblematicum Allonema (Ulrich \& Bassler 1904), a calcareous sclerobiont known from rocks of Ordovician through Permian age (Condra \& Elias 1944, Kiepura 1965, Simonsen \& Cuffey 1980, Jarochowska \& Munnecke 2014). Allonema is an organism composed of branching strings of vesicles with punctate calcareous walls, encrusting carbonate substrates (Ulrich \& Bassler 1904; Figs 1-4). Long considered 


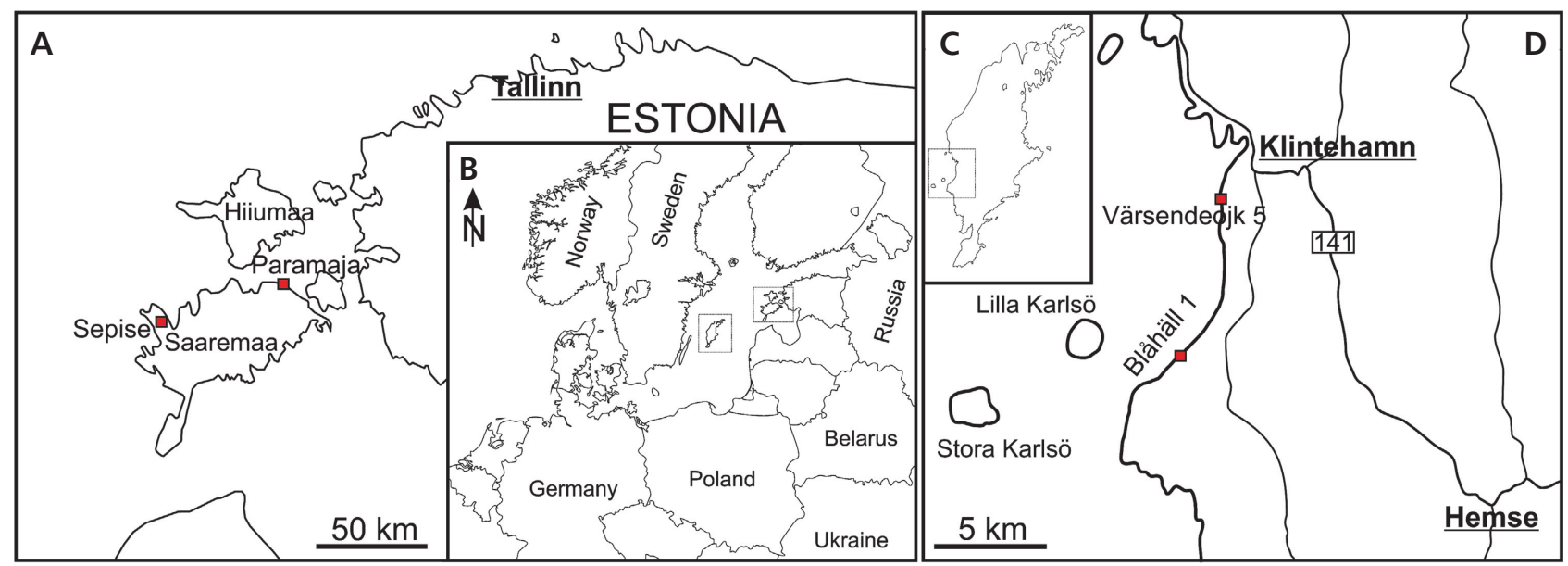

Figure 1. Localities from which new Allonema material for this study was derived. $\bullet$ A - close-up of the NW coast of Estonia, showing the Sepise and Paramaja sections. $\bullet$ B - political map of Europe with Gotland and western Estonia marked with dashed rectangles. $\bullet$ C - outline of Gotland; dashed rectangle marks the area shown in D. • D - close-up of Gotland coast near Klintehamn, with Blåhäll 1 and Värsendeojk 5 marked.

a ctenostome bryozoan (e.g. Ulrich \& Bassler 1904, Kiepura 1965), an opinion rejected by Dzik (1975) and Wilson \& Taylor (2001), Allonema remains in the incertae sedis group of "pseudobryozoans" (Wilson \& Taylor 2001, 2014; Olempska \& Rakowicz 2014). Jarochowska \& Munnecke (2014) demonstrated that sections through Allonema are identical with the problematicum Wetheredella (Wood 1948), another Paleozoic sclerobiont known only from thin sections. Interpretations regarding the ecology and distribution of the two taxa differ widely - Wetheredella had been proposed to be an autotrophic organism based on its common occurrence in shallow-water environments, oncoids, and reefs, i.e. facies typically analyzed using thin sections, whereas Allonema had been mostly reported from off-platform marls and shales, from which extraction of body fossils is possible (Spjeldnaes 1984, Głuchowski 2005, Jarochowska et al. 2013). This discrepancy illustrates the importance of precise and exhaustive taxonomic diagnoses even in problematic fossils. Understanding their ecology may be affected by preservation biases, as well as biases introduced by researchers erecting new taxa based on insufficient samples that do not represent the morphological and ultrastructural variability.

The affinity of Allonema and other pseudobryozoans remains unknown, but many aspects of their ultrastructure and growth habit support the opinion that at least some organisms in this group might be foraminifers (Wood 1948, Elias 1950, Dzik 1975, Taylor \& Wilson 2003, Olempska \& Rakowicz 2014). Allonema shares its growth habit with other problematic organisms for which foraminiferal affinity has been proposed, such as Aphralysia (Bełka 1981, Vachard et al. 2001) Its association with filamentous cyanobacteria forming oncoids and microbially-dominated reefs resembles the oncoid-forming associations of Jurassic encrusting foraminifers and putative microbes (Grad- ziński et al. 2004). So far, however, conclusive evidence for the affinity of Allonema is lacking, and its taxonomy remains a conundrum.

At least seven species of Allonema have been proposed, mostly based on very small number of specimens and overlapping in their proposed morphological variability (summarized in Table 1). Further progress in understanding the ecology and affinity of this genus requires a taxonomic revision based on sufficient samples. In this paper, dimensions of 590 individual vesicles preserved three-dimensionally from five populations from Sweden, Estonia, and Poland are employed to evaluate previously proposed diagnoses and emend them based on quantitative shape parameters.

\section{Material}

Material used in this study is listed in Table 2. Specimens described for the first time from Gotland (EJ- and FH-) are stored at the Institute of Paleontology, University of Erlangen-Nuremberg. New specimens from Estonia at the Institute of Geology, Tallinn University of Technology (GIT) and Natural History Museum, University of Tartu (TUG). Allonema specimens from different localities were in this study treated as separate populations, to account for both taxonomic and environmental effects on morphology. Populations are further identified by locality names as follows. Observations on previously described specimens are included in respective populations below.

Nyhamn. - One valve of a leperditiid arthropod, with Allonema sp. encrustations on the internal side (Fig. 3A, B). The specimen was collected in fossiliferous limestone-marl alternations of the Lower Visby Formation at Nyhamn 1 (Gotland, Sweden; Laufeld 1974), interpreted 
Table 1. Compilation of Allonema species characteristics from previous literature.

\begin{tabular}{|c|c|c|c|c|}
\hline Species & Comments on taxonomy & Vesicle dimensions & Distinctive characters & Reported from localities \\
\hline $\begin{array}{l}\text { A. botelloides } \\
\text { (Ulrich \& Bassler, } \\
\text { 1904) }\end{array}$ & Type species & $\begin{array}{l}\text { Width } 0.25 \mathrm{~mm} \text {, length } c a \\
0.5 \mathrm{~mm} \text { (Ulrich \& Bassler 1904) }\end{array}$ & \multicolumn{2}{|c|}{$\begin{array}{l}\text { Distinguished from A. botellus Gotland (Silurian) - type locality } \\
\text { by its robust aspect and shorter } \\
\text { vesicles }\end{array}$} \\
\hline $\begin{array}{l}\text { A. botellus } \\
\text { (Vine, 1884) }\end{array}$ & $\begin{array}{l}\text { Originally described as } \\
\text { Rhopalonaria botellus }\end{array}$ & $\begin{array}{l}\text { Width } 0.1-0.15 \mathrm{~mm} \text {, length } c a \\
0.5 \mathrm{~mm} \text { (Ulrich \& Bassler 1904) }\end{array}$ & $\begin{array}{l}\text { Some vesicles are club-shaped } \\
\text { and usually exhibit a zooecial } \\
\text { attachment pore (Ulrich \& } \\
\text { Bassler 1904) - not observed } \\
\text { in present study }\end{array}$ & $\begin{array}{l}\text { Gotland (Silurian); "Buildwas } \\
\text { beds of Wenlock shales" (Ulrich } \\
\text { \& Bassler 1904) - type localities }\end{array}$ \\
\hline $\begin{array}{l}\text { A. moniliforme } \\
\text { (Whiteaves, 1891) }\end{array}$ & $\begin{array}{l}\text { Originally described as } \\
\text { Stomatopora moniliformis }\end{array}$ & $\begin{array}{l}\text { Width } 0.1 \text { to } 0.2 \mathrm{~mm} \text {, length } \\
0.3 \text { to } 0.5 \mathrm{~mm} \text { (Kiepura 1965) }\end{array}$ & $\begin{array}{l}\text { Similar to A. botelloides, but } \\
\text { with slightly greater average } \\
\text { width and bead-like vesicles } \\
\text { (Ulrich \& Bassler 1904) }\end{array}$ & $\begin{array}{l}\text { Hay River, Canada - type } \\
\text { locality (Devonian); Skały, Holy } \\
\text { Cross Mountains (Middle } \\
\text { Devonian) }\end{array}$ \\
\hline $\begin{array}{l}\text { A. m. aggregatum } \\
\text { (Ulrich \& Bassler, } \\
\text { 1904) }\end{array}$ & & $\begin{array}{l}\text { Width } 0.2 \text { to } 0.48 \mathrm{~mm} \text {, length } \\
0.4 \text { to } 1.0 \mathrm{~mm} \text { (Kiepura 1965) }\end{array}$ & & $\begin{array}{l}\text { Hamilton Fm., Michigan - type } \\
\text { locality; Skały, Holy Cross } \\
\text { Mountains (Middle Devonian) }\end{array}$ \\
\hline $\begin{array}{l}\text { A.m. parvum } \\
\text { Kiepura, 1965) }\end{array}$ & & $\begin{array}{l}\text { Width } 0.03-0.07 \mathrm{~mm} \text {, length } \\
0.11-0.17 \text { (Kiepura 1965) }\end{array}$ & & $\begin{array}{l}\text { Skały, Holy Cross Mountains } \\
\text { (Middle Devonian) - type } \\
\text { locality }\end{array}$ \\
\hline $\begin{array}{l}\text { A. fusiforme } \\
\text { (Nicholson \& } \\
\text { Etheridge, 1877) }\end{array}$ & $\begin{array}{l}\text { Originally described as } \\
\text { Ascodictyon fusiforme }\end{array}$ & $\begin{array}{l}\text { Similar as in A. subfusiforme } \\
\text { (Ulrich \& Bassler 1904) }\end{array}$ & $\begin{array}{l}\text { Vesicles are frequently } \\
\text { isolated, fusiform, often joined } \\
\text { by long "necks" }\end{array}$ & $\begin{array}{l}\text { Hamilton Fm., Michigan; Widder } \\
\text { Fm., Ontario (Middle Devonian), } \\
\text { Falls of the Ohio (Devonian) }\end{array}$ \\
\hline $\begin{array}{l}\text { A. subfusiforme } \\
\text { (Ulrich \& Bassler, } \\
\text { 1904) }\end{array}$ & & $\begin{array}{l}\text { Vesicles very variable in size, } \\
\text { from } 0.22 \text { wide and } 0.4 \mathrm{~mm} \text { long, } \\
\text { to } 0.6 \mathrm{~mm} \text { wide and } 1.0 \mathrm{~mm} \text { long. } \\
\text { On average } 0.4 \mathrm{~mm} \text { wide and } \\
0.7 \mathrm{~mm} \text { long (Ulrich \& Bassler } \\
1904 \text { ) }\end{array}$ & $\begin{array}{l}\text { Larger and more regular than } \\
\text { A. waldronense }\end{array}$ & Gotland (Silurian) - type locality \\
\hline $\begin{array}{l}\text { A. waldronense } \\
\text { (Ulrich \& Bassler, } \\
\text { 1904) }\end{array}$ & & $\begin{array}{l}\text { Width } 0.3 \mathrm{~mm} \text {, length } c a 0.5 \mathrm{~mm} \\
\text { (Ulrich \& Bassler 1904) }\end{array}$ & $\begin{array}{l}\text { Vesicles show great diversity } \\
\text { of forms. } \\
\text { Similar to A. fusiforme and } A \text {. } \\
\text { subfusiforme but with smaller } \\
\text { vesicles }\end{array}$ & $\begin{array}{l}\text { Waldron Shale, Indiana } \\
\text { (Wenlock) - type locality }\end{array}$ \\
\hline $\begin{array}{l}\text { Allonema? } \\
\text { minimum } \\
\text { (Ulrich \& Bassler, } \\
\text { 1904) }\end{array}$ & Probably not Allonema at all & $\begin{array}{l}\text { Width } 0.1 \mathrm{~mm} \text {, length } 0.1 \text { to } \\
0.28 \mathrm{~mm} \text { (Ulrich \& Bassler 1904) }\end{array}$ & $\begin{array}{l}\text { Vesicles often pear-shaped, } \\
\text { with a single pore. No punctae }\end{array}$ & $\begin{array}{l}\text { Upper Coal Measures, Illinois } \\
\text { (Pennsylvanian) - type locality }\end{array}$ \\
\hline $\begin{array}{l}\text { A. silurica } \\
\text { (Wood, 1948) }\end{array}$ & $\begin{array}{l}\text { Originally described as } \\
\text { Wetheredella silurica, moved } \\
\text { to the genus Allonema by } \\
\text { Jarochowska \& Munnecke } \\
\text { (2014) }\end{array}$ & & & $\begin{array}{l}\text { Much Wenlock Limestone Fm., } \\
\text { May Hill, Gloucestershire, UK } \\
\text { (Wenlock) - type locality; } \\
\text { reported from Gotland }\end{array}$ \\
\hline
\end{tabular}

as deposited in a distal shelf setting (Munnecke et al. 2003). Age: Telychian, Llandovery, lower Silurian; Pterospathodus amorphognathoides conodont Zone (Jeppsson et al. 2006). Coordinates: $\lambda$ N 57 $45^{\prime} 51.88^{\prime \prime}$, $\varphi \mathrm{E} 18^{\circ} 24^{\prime} 55.26^{\prime \prime}$.

Jaani. - Brachiopods and rugose corals from the Paramaja cliff at Jaani (Saaremaa, Estonia; Figs 2B, C, 3C, D). The cliff is known as a rich fossil locality and the stratotype of the Paramaja Member of the Jaani Formation (Conochitina tuba Zone, Sheinwoodian, Nestor 1984). Exposed marlstones are rich in brachiopods, trilobites, rugose corals, and cornulitids (Vinn \& Wilson 2013). Pyritization of skeletal fragments and burrows is common. Lithological composition of rocks and associated fauna suggest a quiet-water environment at the boundary of the open shelf and transitional facies zone (Hints et al. 2008). Coordinates: $\lambda$ N 58 $36^{\prime} 56^{\prime \prime}, \varphi$ E $22^{\circ} 53^{\prime} 51^{\prime \prime}$.

Sepise. - At Sepise (Saaremaa, Estonia) nodular limestones of Jaagarahu Formation are exposed. Raukas \& Teedumäe (1997) characterized the Jaagarahu Fm. in northwestern Saaremaa as very variable, prevailingly sparitic coral-stromatoporoid limestones including reefs and bioherms, and fine-grained skeletal and pelletal grainstones, and inferred shallow-water environment of deposition. The age of the Jaagarahu Fm. is upper Sheinwoodian to lowermost Homerian (Wenlock; Männik 2014). Limestones at Sepise are rich in tabulate corals and other shelly fossils. The outcrop is recently becoming overgrown by vegetation. Coordinates: $\lambda$ N $58^{\circ} 27^{\prime} 18.4608^{\prime \prime}$, $\varphi$ E $22^{\circ} 00^{\circ} 28.7496^{\prime \prime}$. 
Table 2. Allonema specimens used in this study.

\begin{tabular}{|c|c|c|c|c|c|}
\hline Collection ID & Substrate organism & Locality & Lithostratigraphy & Age & Associated sclerobionts \\
\hline FH-2014-01 & Unidentified & Värsendeojk 5, Gotland & Svarvare Mb., Fröjel Fm. & O. b. longa Zone, Homerian & \\
\hline FH-2014-02 & Unidentified & Värsendeojk 5, Gotland & Svarvare Mb., Fröjel Fm. & O. b. longa Zone, Homerian & Condranema parvula \\
\hline FH-2014-03 & Brachiopod & Värsendeojk 5, Gotland & Svarvare Mb., Fröjel Fm. & O. b. longa Zone, Homerian & \\
\hline FH-2014-04 & Unidentified & Värsendeojk 5, Gotland & Svarvare Mb., Fröjel Fm. & O. b. longa Zone, Homerian & \\
\hline FH-2014-05 & Unidentified & Värsendeojk 5, Gotland & Svarvare Mb., Fröjel Fm. & O. b. longa Zone, Homerian & \\
\hline FH-2014-06 & Bryozoan & Värsendeojk 5, Gotland & Svarvare Mb., Fröjel Fm. & O. b. longa Zone, Homerian & \\
\hline FH-2014-07 & Unidentified & Värsendeojk 5, Gotland & Svarvare Mb., Fröjel Fm. & O. b. longa Zone, Homerian & \\
\hline FH-2014-08 & Unidentified & Värsendeojk 5, Gotland & Svarvare Mb., Fröjel Fm. & O. b. longa Zone, Homerian & \\
\hline FH-2014-09 & Eoplectodonta sp. & Värsendeojk 5, Gotland & Svarvare Mb., Fröjel Fm. & O. b. longa Zone, Homerian & \\
\hline FH-2014-10 & Unidentified & Värsendeojk 5, Gotland & Svarvare Mb., Fröjel Fm. & O. b. longa Zone, Homerian & \\
\hline FH-2014-11 & Unidentified & Värsendeojk 5, Gotland & Svarvare Mb., Fröjel Fm. & O. b. longa Zone, Homerian & \\
\hline FH-2014-12 & Unidentified & Värsendeojk 5, Gotland & Svarvare Mb., Fröjel Fm. & O. b. longa Zone, Homerian & Condranema parvula \\
\hline FH-2014-13 & Unidentified & Värsendeojk 5, Gotland & Svarvare Mb., Fröjel Fm. & O. b. longa Zone, Homerian & \\
\hline FH-2014-14 & Unidentified & Värsendeojk 5, Gotland & Svarvare Mb., Fröjel Fm. & O. b. longa Zone, Homerian & \\
\hline FH-2014-15 & Unidentified & Värsendeojk 5, Gotland & Svarvare Mb., Fröjel Fm. & O. b. longa Zone, Homerian & \\
\hline FH-2014-16 & $\begin{array}{l}\text { Bryozoan growing } \\
\text { on an unidentified } \\
\text { shell fragment }\end{array}$ & Värsendeojk 5, Gotland & Svarvare Mb., Fröjel Fm. & O. b. longa Zone, Homerian & \\
\hline FH-2014-17 & $\begin{array}{l}\text { Unidentified } \\
\text { brachiopod }\end{array}$ & Värsendeojk 5, Gotland & Svarvare Mb., Fröjel Fm. & O. b. longa Zone, Homerian & Condranema parvula \\
\hline EJ-2013-001 & Trilobite & Blåhäll 1, Gotland & $\begin{array}{l}\text { Mulde Brick-clay Mb., } \\
\text { Halla Fm. }\end{array}$ & O. b. longa Zone, Homerian & Condranema parvula \\
\hline EJ-2013-002 & Trilobite & Blåhäll 1, Gotland & $\begin{array}{l}\text { Mulde Brick-clay Mb., } \\
\text { Halla Fm. }\end{array}$ & O. b. longa Zone, Homerian & $\begin{array}{l}\text { Condranema parvula, } \\
\text { bryozoans }\end{array}$ \\
\hline EJ-2013-003 & Bryozoan & Blåhäll 1, Gotland & $\begin{array}{l}\text { Mulde Brick-clay Mb., } \\
\text { Halla Fm. }\end{array}$ & O. b. longa Zone, Homerian & Condranema parvula \\
\hline EJ-2014-001 & $\begin{array}{l}\text { Leperditiid } \\
\text { arthropod }\end{array}$ & Nyhamn 1, Gotland & Lower Visby Fm. & $\begin{array}{l}\text { Pt. amorphognathoides Zone, } \\
\text { Telychian }\end{array}$ & Bryozoans \\
\hline GIT 687-128 & Unidentified & Sepise, Saaremaa & Jaagarahu Fm. & $\begin{array}{l}\text { Upper Sheinwoodian } \\
\text { to lowermost Homerian }\end{array}$ & $\begin{array}{l}\text { Palaeoconchus sp., } \\
\text { Corynotrypa sp. }\end{array}$ \\
\hline GIT $687-132$ & Crinoid & Sepise, Saaremaa, & Jaagarahu Fm. & $\begin{array}{l}\text { Upper Sheinwoodian } \\
\text { to lowermost Homerian }\end{array}$ & Palaeoconchus sp. \\
\hline GIT 700-143 & $\begin{array}{l}\text { Estonirhynchia } \\
\text { estonica }\end{array}$ & Jaani, Saaremaa & Jaani Fm. & C. tuba Zone, Sheinwoodian & \\
\hline GIT 700-159 & $\begin{array}{l}\text { Estonirhynchia } \\
\text { estonica }\end{array}$ & Jaani, Saaremaa & Jaani Fm. & C. tuba Zone, Sheinwoodian & Bryozoans \\
\hline GIT 700-222 & $\begin{array}{l}\text { Estonirhynchia } \\
\text { estonica }\end{array}$ & Jaani, Saaremaa & Jaani Fm. & C. tuba Zone, Sheinwoodian & $\begin{array}{l}\text { Ascodictyon venustum, } \\
\text { bryozoans, Palaeoconchus } \\
\text { aff. tenuis }\end{array}$ \\
\hline GIT 700-285 & $\begin{array}{l}\text { Estonirhynchia } \\
\text { estonica }\end{array}$ & Jaani, Saaremaa & Jaani Fm. & C. tuba Zone, Sheinwoodian & $\begin{array}{l}\text { Craniops implicatus, } \\
\text { Palaeoconchus aff. tenuis }\end{array}$ \\
\hline TUG 1704-1 & Rugose coral & Jaani, Saaremaa & Jaani Fm. & C. tuba Zone, Sheinwoodian & $\begin{array}{l}\text { Condranema parvula, } \\
\text { Palaeoconchus sp. }\end{array}$ \\
\hline TUG 1704-2 & Rugose coral & Jaani, Saaremaa & Jaani Fm. & C. tuba Zone, Sheinwoodian & \\
\hline TUG 1704-3 & Rugose coral & Jaani, Saaremaa & Jaani Fm. & C. tuba Zone, Sheinwoodian & \\
\hline TUG 1704-4 & Rugose coral & Jaani, Saaremaa & Jaani Fm. & C. tuba Zone, Sheinwoodian & $\begin{array}{l}\text { Condranema parvula, } \\
\text { bryozoans, Palaeoconchus } \\
\text { sp., Craniops sp. }\end{array}$ \\
\hline TUG 1704-5 & Rugose coral & Jaani, Saaremaa & Jaani Fm. & C. tuba Zone, Sheinwoodian & $\begin{array}{l}\text { Bryozoans, Craniops sp., } \\
\text { Palaeoconchus sp., } \\
\text { Condranema parvula }\end{array}$ \\
\hline TUG 1704-6 & $\begin{array}{l}\text { Estonirhynchia } \\
\text { estonica }\end{array}$ & Jaani, Saaremaa & Jaani Fm. & C. tuba Zone, Sheinwoodian & Bryozoans \\
\hline
\end{tabular}


Mulde. - Trilobite and brachiopod fragments from marls of the Mulde Brick-clay Member of the Halla Formation at Blåhäll 1 (Gotland, Sweden; Figs 1, 2A). The locality was previously described by Laufeld (1974) and Calner \& Jeppsson (2003). It represents a platform slope setting with rich and diverse encruster fauna (Spjeldnaes 1984, Jarochowska \& Munnecke 2014). Age: Homerian, Wenlock, middle Silurian; Ozarkodina bohemica longa conodont Zone (Jeppsson et al. 2006). Coordinates: $\lambda$ N 57 $18^{\prime} 44.65^{\prime \prime}$, $\varphi$ E $18^{\circ} 09^{\prime} 19.79^{\prime \prime}$.

Svarvare. - Brachiopods, bryozoans, and unidentified clasts from the Svarvare Mudstone Member of the Fröjel Formation at Värsendeojk 5 (Gotland, Sweden; Figs 1, 3E, F, 4). The Svarvare Mb. was characterized by Calner (1999) and Calner \& Jeppsson (2003) as dark, organic-rich, condensed argillaceous mud- and wackestones grading upwards into siliciclastic mudstones deposited in a platform slope setting. Hierl (2014) characterized the fauna of the Svarvare Mb. as dominated by brachiopods, including $D i$ coelosia sp., indicating low water energy. Associated fauna consists of trilobites and corals, with a smaller proportion of crinoids, bryozoans, ostracods, and tentaculitids. Age: Homerian, Wenlock, middle Silurian; Ozarkodina bohemica longa conodont Zone (Jeppsson et al. 2006). Coordinates: sampling transect along the shore, from $\lambda \mathrm{N} 57^{\circ} 21^{\prime} 40.8^{\prime \prime}, \varphi \mathrm{E} 18^{\circ} 10^{\prime} 25.1^{\prime \prime}$ to $\lambda \mathrm{N} 57^{\circ} 21^{\prime} 40.8^{\prime \prime}$, $\varphi \mathrm{E} 18^{\circ} 10^{\prime} 26.0^{\prime \prime}$.

Skaty. - Measurements of Allonema moniliforme aggregatum used in the analysis were provided by Kiepura (1965). Original specimens could not be found in the collections of the Institute of Paleobiology, Polish Academy of Science (A. Halamski, personal communication 2015). They were described from several trenches in the Skały section located in the Holy Cross Mountains, central Poland. Kiepura (1965) reported that Allonema specimens were mostly found encrusting brachiopods from marly shales and marls of the Skały Formation, formed in a platform slope environment. Age: originally reported as Givetian (Kiepura 1965), according to newer studies the Skały Fm. spans the Eifelian-Givetian boundary (Szulczewski 1995). Coordinates: $\lambda \mathrm{N} 50^{\circ} 53^{\prime} 37.26^{\prime \prime}, \varphi \mathrm{E} 21^{\circ} 9^{\prime} 42.57^{\prime \prime}$.

\section{Methods}

Specimens from the Mulde and Svarvare populations were extracted from marly matrix using the surfactant Rewoquat according to the method described by Jarochowska et al. (2013). Other specimens were collected as body fossils weathered out from rock matrix. All were washed in an ultrasonic bath and photographed in reflected light. A subset was sputter-coated with gold and examined under SEM
(TESCAN VegallXMU). Lengths and widths of complete, undamaged Allonema vesicles were measured from calibrated photographs in Adobe Photoshop. Lengths of curved vesicles were approximated by fitting several straight segments to the vesicle shape. Attempts to record vesicles belonging to the same specimen failed, as in most specimens the preservation did not allow distinguishing between overlapping chains. Measurements are provided in Appendix 1. Specimens from Nyhamn were too few to be included in regression analysis.

The relationship between vesicle dimensions in Allonema populations was examined using major axis regression (Legendre \& Legendre 1998) in R version 3.2.2 (R Core Team 2015). Equality of regression slopes fitted to each population was tested using the Sidak adjustment (Westfall \& Young 1993) implemented in the "smatr" package (Warton et al. 2012). Confidence intervals for each population separately were plotted using lmodel2. For specimens from Svarvare and Sepise, analyses were performed using two versions of the measurement dataset: complete and restricted. The complete version included outliers characterized by size and proportions different from the main dataset, marked in Appendix 1 as "rounded" (see also Fig. 5). In the restricted version these specimens were excluded when characterizing the dimensions within populations.

\section{Results}

Examined substrates showed different degrees of infestation, from single chains formed by less than ten vesicles (Nyhamn, Sepise, Figs 2A, B, 3A, B, F, 4) to dense, complex, overlapping networks (particularly from Jaani, Fig. 3C-E). Encrustation took place at least partially post-mortem, as the chains grew across the commissure in brachiopods and were observed on the internal side of a disarticulated arthropod valve (Fig. 3A, B). No preferred direction of growth was observed; in substrates with low density of Allonema the directions were approximately radial (Fig. 2B), i.e. branches starting in one site spread apart. Associated encrusters were mostly bryozoans, including Corynotrypa sp., microconchids Palaeoconchus sp., brachiopods belonging to the genus Craniops, and calcareous problematica Condranema parvula (Condra \& Elias, 1944) and Ascodictyon venustum (Kiepura, 1965). No interactions were observed between Allonema and other encrusters. Also no connections were observed between the only specimen of Ascodictyon venustum and Allonema, an aspect reported by Wilson \& Taylor (2014) from Givetian specimens collected from the Silica Shale in Michigan.

Distribution of vesicle dimensions in examined Allonema populations is shown in Fig. 5 and summarized 
in Table 3. Size ranges reported in the literature (Table 2) are overlain on Fig. 5 as grey dashed rectangles. Based on the relationship between width and height, two groups of populations could be distinguished. The Mulde and Jaani populations were characterized by elongated (up to $1420 \mu \mathrm{m}$ ), narrow (up to $462 \mu \mathrm{m}$ ) vesicles. The Skały population and chains of exceptionally large vesicles from Svarvare and Sepise were similarly long (up to $1000 \mu \mathrm{m}$ ), but thicker and more rounded. The main difference between these two groups is not in the range of absolute dimensions, but in the proportions of vesicles (Fig. 6). Slopes of regression models fitted to vesicle dimensions did not differ significantly at $\alpha=0.005$ within both groups, and differed between them (Table 4).

The Svarvare population did not differ significantly from that from Skały in terms of vesicle proportions, but reached only about half of the size range of the other two, with its maximum length of $549 \mu \mathrm{m}$ and maximum width of $265 \mu \mathrm{m}$. A short Allonema chain in this group was excluded from the regression analysis and marked separately in Fig. 5 as "Svarvare (rounded)". The specimens are shown in Fig. 4A, B, where they co-occur on one substrate with typical Allonema from Svarvare. The tentative exclusion was based on the much larger dimensions and regular, circular shape of the vesicles, which marked them as clearly distinct from the rest of this population. They showed pores characteristic for Allonema, and very narrow $(\mathrm{ca} 70 \mu \mathrm{m})$ constrictions between vesicles. Two chains with outstandingly large vesicles were also observed on specimens from Sepise (Fig. 4C, D). They differ from those from Svarvare in much wider, fused constrictions between vesicles. After excluding these outliers, the slope of regression on main dimensions did not differ significantly from that of the Jaani and Mulde populations (Table 4). However, the size range was much narrower (Table 3 ).

\section{Discussion}

\section{Species identification}

Original descriptions of Allonema species by Ulrich \& Bassler (1904) were based on one or a small number of chains, precluding an assessment of intra- and interspecific variability. Sources of intraspecific variation might include the type of substrate, environmental conditions, and competition for space with other epibionts. In the lack of complex features, Allonema taxonomy has been based on vesicle sizes and shapes (e.g. club-shaped, fusiform, Table 1), an aspect approximated in this study by analyzing vesicle proportions. Here we assume that vesicles observed in the same populations, i.e. collections derived from one type of lithology in one locality, and showing a continuum of di- mensions, represent individual species. All of them correspond poorly to the size ranges reported for previously proposed Allonema taxa (Table 1), supporting the possibility that the large number of proposed species may have resulted from undersampling of intraspecific variability.

Very few vesicles in examined specimens fell within the size range reported for A. botelloides (Table 1, Fig. 5, Ulrich \& Bassler 1904) - although this species was described as common on corals from Gotland, it was not found in the present study.

A. moniliforme encompasses a confounding list of subspecies. The original description by Whiteaves (1891) was based on four specimens with average length of $0.5 \mathrm{~mm}$ and width of $0.2 \mathrm{~mm}$. Ulrich \& Bassler (1904) observed that they were similar to A. botelloides, but broader and with bead-like vesicles. This was contradicted by Kiepura (1965) based on material from the Middle Devonian of the Holy Cross Mountains, which she designated as A. moniliforme moniliforme, implicitly synonymous of $A$. moniliforme of Whiteaves (1891). In this population, the width range was smaller than in A. botelloides $(0.1-0.2 \mathrm{~mm})$, therefore the distinction between the two species remains unclear. Ulrich \& Bassler (1904) introduced the subspecies A. moniliforme aggregatum from the Middle Devonian of the New York state without specifying in what did it differ from A. moniliforme. According to Kiepura (1965), it is characterized by vesicles that are both larger and wider, branch frequently, and show a high variability. Her measurements were included in the present study as a reference population and found to overlap nearly perfectly with size ranges of A. fusiforme and A. subfusiforme, and to encompass entirely the range of dimensions reported for $A$. botelloides. What is more, $A$. waldronense shared the size range with all these species, being distinguished by a more winding growth habit and high variability of vesicles (Ulrich \& Bassler 1904).

Differences between these taxa are based on vesicle shapes, A. fusiforme being fusiform, A. subfusiforme - bottle-shaped with narrow necks (not evidenced, however, by the original illustration), A. botelloides - oblong and sausage-shaped, and A. moniliforme aggregatum showing a wide variety of shapes, including fusiform, club-like, pear-like, elliptical, and rounded. None of the examined populations fell closely within the range of dimensions of any of the above species. Treating the Skały population as a reference for the range of dimensions in A. moniliforme aggregatum, only outlier specimens from two specimens from Sepise (GIT 687-132-4 and GIT 687-128-5) and one specimen from Svarvare (FH-2014-02) were found to correspond to it. Populations from these localities showed a bimodal distribution, consisting of a few large vesicles forming separate chains and falling within the size ranges of A. moniliforme aggregatum (Fig. 4C, D), and the majority of chains of small vesicles differing significantly in 
terms of their proportions (Fig. 5, Table 4). Regression parameters for dimensions in the Sepise population with outliers excluded did not differ significantly from those for the Jaani and Mulde populations, but the size range was closer to the Svarvare population. Regression parameters may have in this case been affected by the small sample size $(\mathrm{N}=41)$, therefore we refrain here from assigning this population to any previously defined species until more material is available.

Size ranges of $A$. moniliforme parvum reported by Kiepura (1965) were inconsistent: she indicated that 12 to 18 vesicles were found over a $2 \mathrm{~mm}$ length, indicating vesicle lengths in the range of 0.11 to $0.17 \mathrm{~mm}$, consistent with measurements on specimen illustration therein; in her Table 6 reported vesicle length was $0.1 \mathrm{~mm}$ and width 0.4 , and measurements from the illustrated specimens indicate width range of 0.03 to $0.07 \mathrm{~mm}$. Dimensions based on the illustration are used here for comparison (Table 1) and indicate that $A$. moniliforme parvum was not found among examined specimens. The same holds for Allonema? minimum, tentatively classified in the genus by Ulrich \& Bassler (1904) based on material from the Pennsylvanian of Illinois. The authors did not observe pores on the surface, but this feature is commonly obliterated in e.g. some vesicles in otherwise punctate chains, or in entire specimens in the case of abraded or strongly cemented material. The presence or absence of pores on the surface cannot be therefore used as a decisive criterion for taxonomic classification, but it can be verified by examining the ultrastructure (Wood 1948, Jarochowska \& Munnecke 2014, Olempska \& Rakowicz 2014). The single large terminal pore illustrated by Ulrich \& Bassler (1904; pl. 67, figs 10,11 ) and the dimensions resemble Corynotrypa sp., a bryozoan observed in the present study in association with Allonema sp.

The group of populations from Mulde and Jaani did not fit to any of the size ranges discussed above. It is, however, clearly distinguished by its elongate appearance. This trait corresponds with the distinctive feature of A. botellus described from the Silurian of Gotland and England (Vine 1884, 1887; Ulrich \& Bassler 1904). We postulate that the continuum of sizes in these two populations ( $\mathrm{N}=358$ in total) encompasses the range reported for A. botellus, and is here demonstrated to be significantly different, and possible to distinguish based on shape parameters, from other populations and species discussed. Mulde and Jaani specimens described in this study can be therefore treated as a more complete representation of intraspecific variability within A. botellus.

The Svarvare population did not differ significantly in terms of vesicle proportions from A. moniliforme aggregatum from Skały, but fell entirely below its size range and close to the range reported for A. moniliforme moniliforme. It also overlapped with the smaller part of
Table 3. Summary of vesicle dimensions in examined Allonema populations.

\begin{tabular}{lrrrrrrr}
\hline & \multicolumn{3}{c}{ Length $[\mu \mathrm{m}]$} & \multicolumn{3}{c}{ Width $[\mu \mathrm{m}]$} \\
\hline Population & $\mathrm{N}$ & Min. & Mean & Max. & Min. & Mean & Max. \\
\hline Jaani & 275 & 70 & 577 & 1420 & 9 & 159 & 462 \\
Mulde & 83 & 240 & 660 & 1280 & 55 & 113 & 185 \\
Sepise (restricted) & 41 & 130 & 322 & 580 & 105 & 167 & 242 \\
Sepise (rounded) & 6 & 383 & 586 & 822 & 322 & 433 & 543 \\
Skały & 32 & 320 & 611 & 1000 & 100 & 323 & 600 \\
Svarvare (restricted) & 146 & 36 & 277 & 549 & 12 & 123 & 265 \\
Svarvare (rounded) & 3 & 406 & 463 & 500 & 386 & 408 & 419 \\
\hline
\end{tabular}

the Sepise population. In both groups the slope of regression line was near 0.5 (0.4 for Svarvare and 0.6 for Sepise, Fig. 6), i.e. the length to width ratio was near 2:1. These populations can be reliably distinguished from A. botellus based on this shape parameter (Table 4). The continuum of dimensions encompasses A. moniliforme moniliforme and $A$. minimum, suggesting that their previously reported size ranges were small samples from this continuum. Therefore we postulate that A. minimum is a junior synonym of $A$. moniliforme, and the subspecies A. moniliforme moniliforme should be abandoned. Based on quantitative data available so far, A. moniliforme and A. moniliforme aggregatum have the same proportions (Fig. 6) but are clearly distinct in terms of size ranges. This permits to distinguish them as two species that can be identified based on their shape parameters. Therefore we propose to bring the subspecies A. $m$. aggregatum to the rank of species as A. aggregatum (Ulrich \& Bassler 1904).

\section{Controls on intraspecific variability}

Except for the Skały population, all discussed specimens were early to middle Silurian and derived from a narrow area (Gotland and Saaremaa). All but the population from Sepise grew in calm, muddy environments below the fair-weather wave base. This homogeneity of sampled sites permits to speculate that differences between the populations were not phenotypic plasticity in reaction to water energy, turbidity or light conditions. Other factors that might affect vesicle shapes, particularly biotic interactions such as competition cannot be ruled out. Although A. botellus showed denser infestation, the species occurred also as solitary, rare chains (Figs 2B, 3A, B), where it could be clearly identified as the highly elongate form. This suggests that competition for space did not determine the shape of this species, unless Allonema competed with soft-bodied organisms, which could not be detected on fossil substrates. 

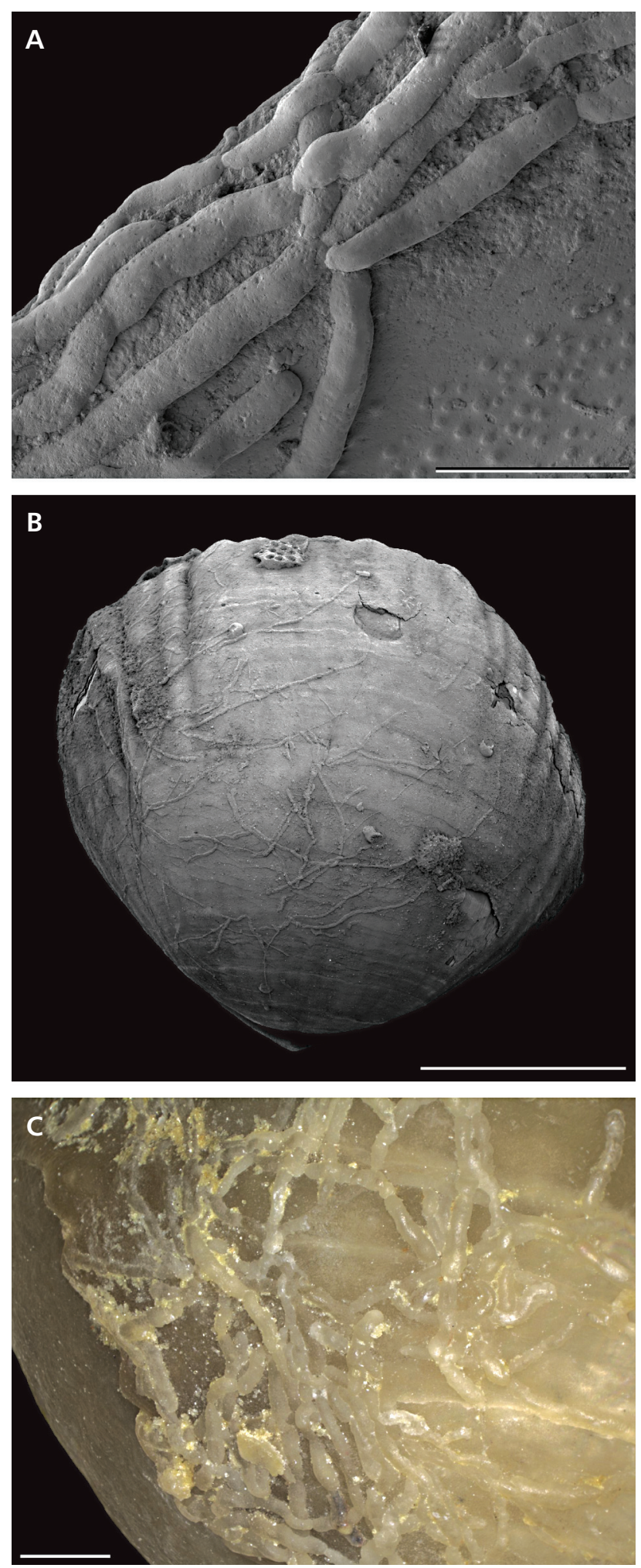

Figure 2. Allonema botellus from the Silurian of Sweden and Estonia. - A - EJ-2013-001. Trilobite fragment from the Mulde Brick-clay Mb. at Blåhäll 1 (Gotland), encrusted with Condranema parvula, scale bar $500 \mu \mathrm{m}$. • B , C - brachiopod Estonirhynchia estonica from the Jaani Fm. at Jaani (Saaremaa); B - GIT-700-222, scale bar 5 mm; C - GIT 700-143, scale bar $1 \mathrm{~mm}$.

\section{Systematic paleontology}

Kingdom, phylum, class, order and family incertae sedis

Genus Allonema Ulrich \& Bassler, 1904

1884 Rhopalonaria Vine (partim).

1887 Rhopalonaria Vine (partim).

Type species. - Allonema botellus (Vine, 1884).

\section{Allonema botellus (Vine, 1884)}

Figures 2, 3A-D

1884 Rhopalonaria Vine (partim), p. 87.

1887 Rhopalonaria Vine (partim), p. 179

1904 Allonema botellus (Vine, 1884). - Ulrich \& Bassler, pp. 281-282, pl. 67.1.

1948 Wetheredella silurica sp. nov.; Wood, pp. 21-22, pls $3 \mathrm{~b}, 5 \mathrm{~b}$.

2014 Allonema silurica (Wood, 1948). - Jarochowska \& Munnecke, pp. 653-656, figs 1a-f, 2a-c, 5a, c.

Material. - Fourteen substrates (brachiopods, trilobites, rugose corals, a bryozoan, and a leperditiid arthropod) from the Mulde Brick-clay Mb. of the Halla Fm. at Blåhäll 1 (Gotland) and the Jaani Fm. at the Paramaja cliff (Saaremaa) encrusted with $A$. botellus. Description is based on measurements of 358 vesicles.

Diagnosis (emended). - A. botellus is distinguished from other Allonema species by the elongate aspect of its vesicles, i.e. their length to width ratio ranging between ca 10:1 to 45:1 (Fig. 6).

Description. - Sparsely branching chains consisting of elongate vesicles ranging in the width from 9 to $399 \mu \mathrm{m}$ (average $149 \mu \mathrm{m}$ ) and from $70 \mu \mathrm{m}$ to $1420 \mu \mathrm{m}$ in length (average $597 \mu \mathrm{m}$ ). Pores are visible on the surface of well-preserved specimens, but obliterated in most specimens by diagenesis or abrasion.

Occurrence. - Reported from the Silurian of England, Gotland, and Saaremaa. Known in its two-dimensional aspects as Wetheredella silurica (partim?), in which it is difficult to distinguish from other species of Allonema. Taking into account reported occurrences of Wetheredella, its stratigraphic range may extend at least into the Ordovician (summarized in Jarochowska \& Munnecke 2014).

\section{Allonema moniliforme (Whiteaves, 1891)}

Figure 3E, F

1891 Stomatopora moniliformis Whiteaves, p. 12, fig. 10, pl. 28. 

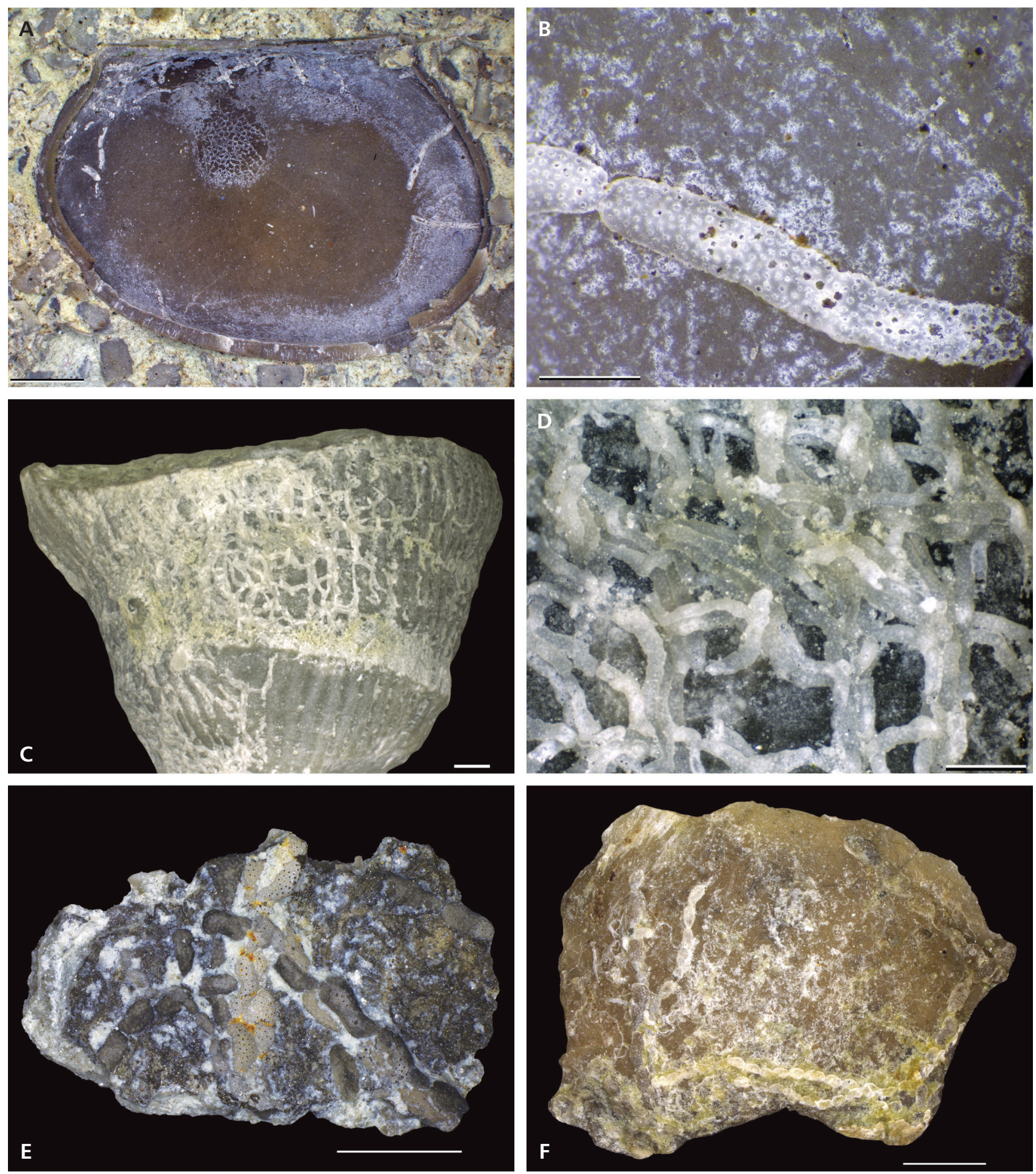

Figure 3. Allonema encrustations on components from the Silurian of Sweden (A, B, E, F) and Estonia (C, D). • A, B - EJ-2014-001. Allonema botellus on the inner side of a leperditiid arthropod valve from the Lower Visby Fm. at Nyhamn 1 (Gotland); A - scale bar $2 \mathrm{~mm}$; B - scale bar $500 \mu \mathrm{m}$. - C, D - TUG 1704-5. A. botellus on a rugose coral from the Jaani Fm. at Jaani (Saaremaa); C - scale bar $1 \mathrm{~mm}$; D - scale bar 500 $\mu$ m. • E - FH-2014-11. A. moniliforme on an unidentified clast from the Svarvare Mb. at Värsendeojk 5 (Gotland), scale bar $1 \mathrm{~mm}$. $\bullet \mathrm{F}-\mathrm{FH}-2014-17$. A. moniliforme and Condranema parvula on an unidentified brachiopod from the Svarvare Mb. at Värsendeojk 5, scale bar $1 \mathrm{~mm}$. 

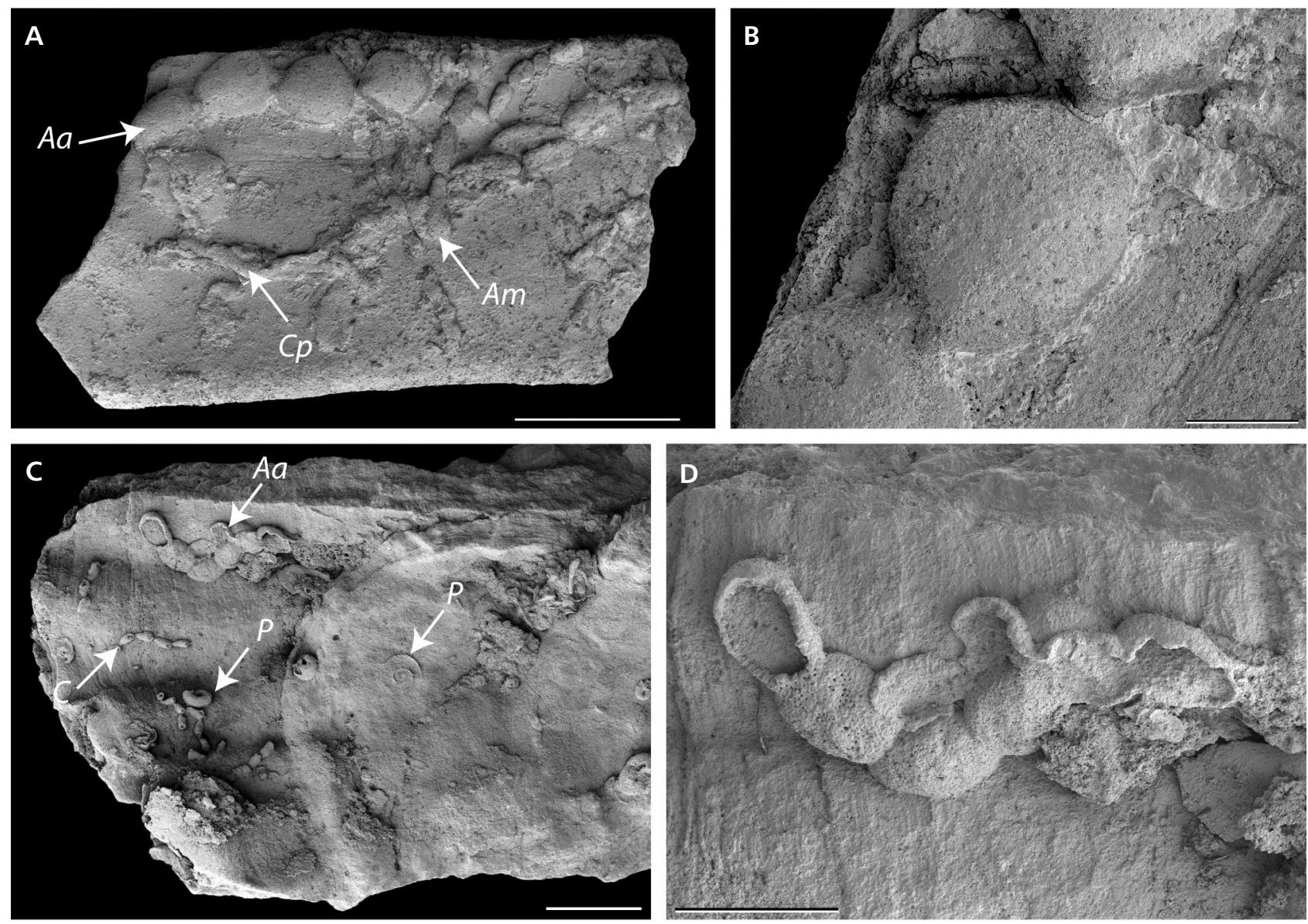

Figure 4. Allonema aggregatum from the Silurian of Sweden and Estonia. - A, B - FH-2014-02. Unidentified clast from the Svarvare Mb. at Värsendeojk 5 (Gotland), encrusted by A. aggregatum (Aa), A. moniliforme (Am), and Condranema parvula (Cp); A - scale bar $1 \mathrm{~mm}$; B - scale bar $500 \mu \mathrm{m}$. C , D - GIT-687-128. Unidentified clast from the Jaagarahu Fm. at Sepise (Saaremaa), encrusted with A. aggregatum (Aa), Allonema sp., Palaeoconchus sp. (P), and Corynotrypa sp. (C); C - scale bar $2 \mathrm{~mm}$; D - scale bar $1 \mathrm{~mm}$.

1904 Allonema moniliforme (Whiteaves, 1891). - Ulrich \& Bassler, p. 282, pl. 67.

1904 Allonema minimum? sp. nov.; Ulrich \& Bassler, pp. 284-285, pl. 67.

1965 Allonema moniliforme moniliforme (Whiteaves, 1891). - Kiepura, pp. 26-28, fig. 4, pl. 4, fig. 1, pl. 6, figs 1,6 .

Material. - Nineteen components (unidentified carbonate grains, a bryozoan, a brachiopod, and a fragment of articulated crinoid stem) from the Svarvare $\mathrm{Mb}$. of the Fröjel Fm. at Värsendeojk 5 (Gotland) encrusted with A. moniliforme. Description is based on measurements of 146 vesicles.

Diagnosis (emended). - A. moniliforme is distinguished from other species of Allonema by vesicle length to width ratio close to 2:1 (Fig. 6). It is similar to A. aggregatum in terms of proportions, but differs in the smaller size of vesicles (not exceeding $c a 300 \mu \mathrm{m}$ in width and $c a 600 \mu \mathrm{m}$ in length).
Description. - Sparsely branching colonies consisting of plump vesicles ranging in the width from 12 to $265 \mu \mathrm{m}$ (average $123 \mu \mathrm{m}$ ) and from $36 \mu \mathrm{m}$ to $549 \mu \mathrm{m}$ in length (average $277 \mu \mathrm{m})$. Pores are visible on the surface of well-preserved specimens, but obliterated in most specimens by diagenesis or abrasion.

Occurrence. - Reported from the Middle Devonian of the Northwest Territories (Canada) and Poland, here also from the Wenlock (middle Silurian) of Gotland. See comments on the stratigraphic range of $A$. botellus above.

\section{Allonema aggregatum (Ulrich \& Bassler, 1904)}

Figure 4

1904 Allonema moniliforme var. aggregatum var. nov.; Ulrich \& Bassler, pp. 282-283, pl. 67.

1965 Allonema moniliforme aggregatum Ulrich \& Bassler, 1904. - Kiepura, pp. 28-30, fig. 5, pl. 5, figs 1, 2. 


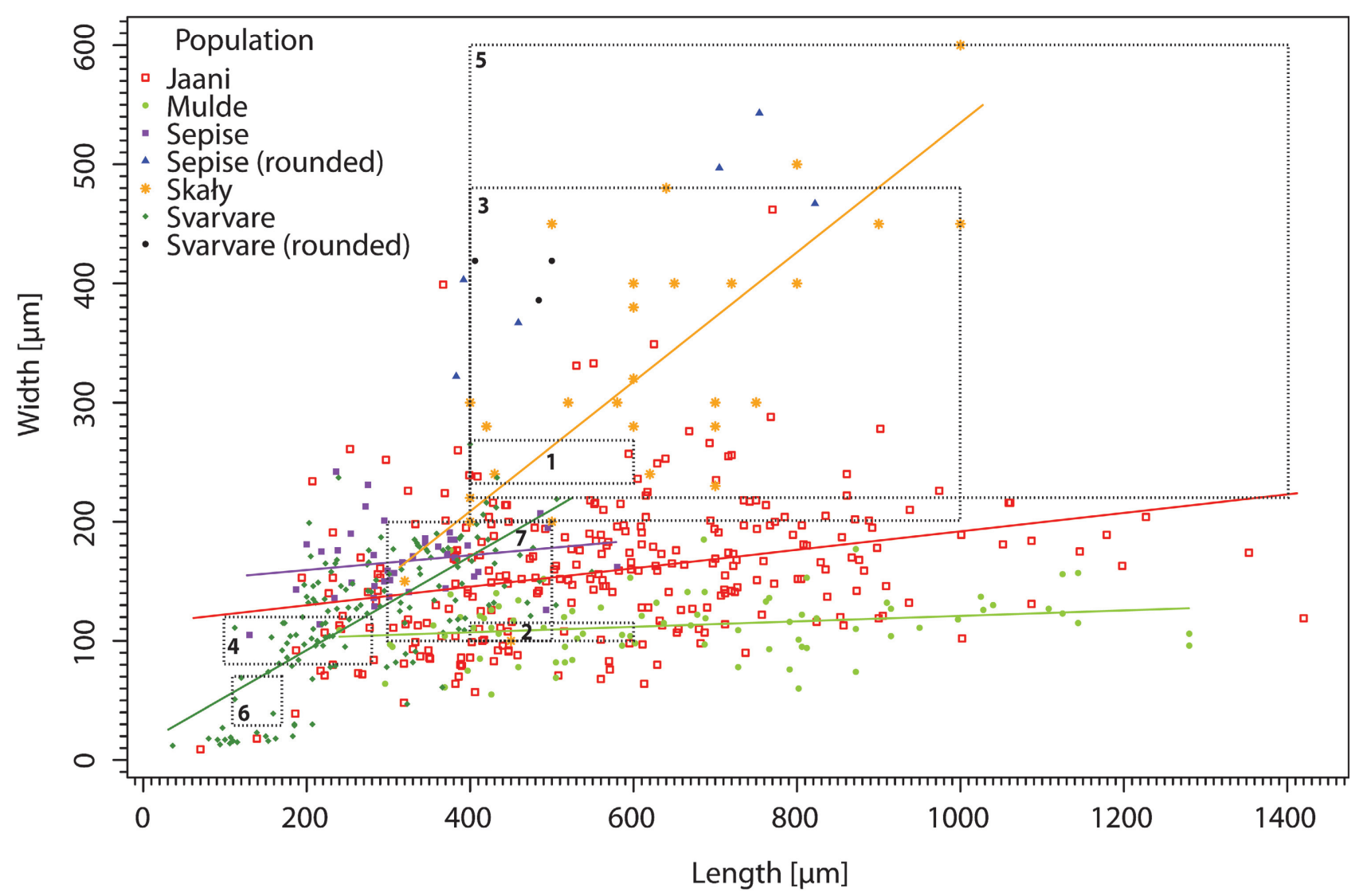

Figure 5. Scatter plot of dimensions of studied Allonema specimens, with major axis regression lines fitted for each population. Dashed boxes indicate size ranges for Allonema species reported in the literature (Table 1): 1 - A. botelloides (Ulrich \& Bassler, 1904), 2 - A. botellus (Vine, 1884), 3-A. moniliforme aggregatum (Kiepura, 1965), 4-A. minimum (Ulrich \& Bassler, 1904), 5-A. fusiforme and A. subfusiforme (Ulrich \& Bassler, 1904), 6-A. moniliforme parvum (Kiepura, 1965), 7 -A. moniliforme moniliforme.

Material. - Two specimens from the Jaagarahu Fm. at Sepise (Saaremaa), encrusting an unidentified clast (GIT 687-132) and a crinoid stem (GIT 687-128), and one specimen encrusting an unidentified clast from the Svarvare $\mathrm{Mb}$. of the Fröjel Fm. at Värsendeojk 5 in Gotland (FH-2014-02). Description is based on measurements of 9 vesicles marked in Fig. 5 as "Sepise (rounded)" and "Svarvare (rounded)".

Diagnosis (emended). - A. aggregatum is distinguished from other species of Allonema by vesicle length to width ratio below 2:1 (Fig. 6) and the large size of vesicles length larger than $c a 350 \mu \mathrm{m}$ and width larger than $c a$ $300 \mu \mathrm{m}$ (Fig. 5, Table 4).

Description. - Branching chains were not observed, but this may be due to the very small sample size. Vesicles are plump, nearly round or egg-shaped in their outline. In all studied specimens pores were visible on the surface and in broken vesicle walls (Fig. 4C). A. aggregatum co-occurs with smaller Allonema sp. (see below) on substrates from Sepise, and with A. moniliforme on specimens from Värsendeojk 5.
Table 4. P-values for pairwise comparisons of major axis regression slopes for dimensions in examined Allonema populations. Asterisks indicate significantly different pairs at $\alpha=0.005$.

\begin{tabular}{lll}
\hline Population 1 & Population 2 & P-value \\
\hline Jaani & Mulde & 0.1042 \\
Jaani & Sepise (restricted dataset) & 1.0000 \\
Jaani & Skały & $0.0007^{*}$ \\
Jaani & Svarvare (restricted dataset) & $0.0000^{*}$ \\
Mulde & Sepise (restricted dataset) & 1.0000 \\
Mulde & Skały & $0.0002^{*}$ \\
Mulde & Svarvare (restricted dataset) & $0.0000^{*}$ \\
Sepise (restricted dataset) & Skały & $0.0013^{*}$ \\
Sepise (restricted dataset) & Svarvare (restricted dataset) & $0.0004^{*}$ \\
Skały & Svarvare (restricted dataset) & 0.9625 \\
Jaani & Sepise & $0.0000^{*}$ \\
Jaani & Svarvare & $0.0000^{*}$ \\
Mulde & Sepise & $0.0000^{*}$ \\
Mulde & Svarvare & $0.0000^{*}$ \\
Sepise & Skały & 0.9997 \\
Sepise & Svarvare & 0.8788 \\
Skały & Svarvare & 1.0000 \\
\hline
\end{tabular}




\section{Svarvare (restricted)}

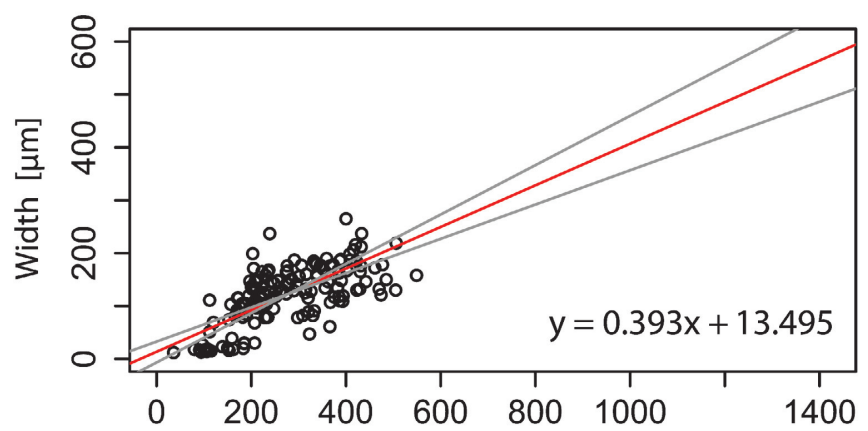

Skały

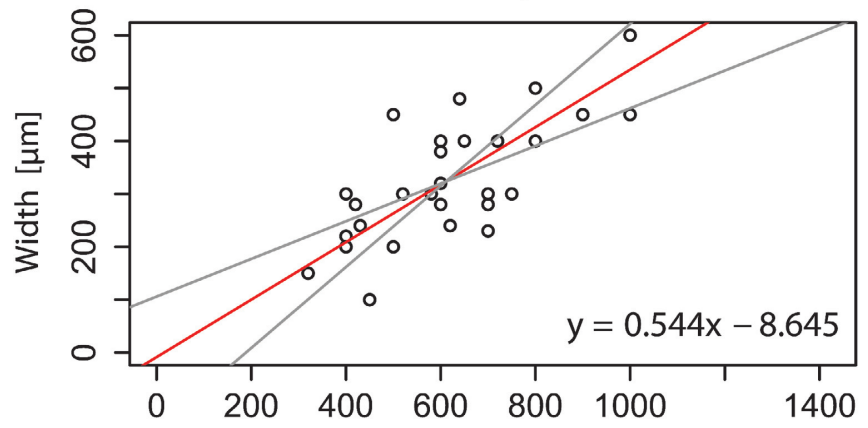

Sepise

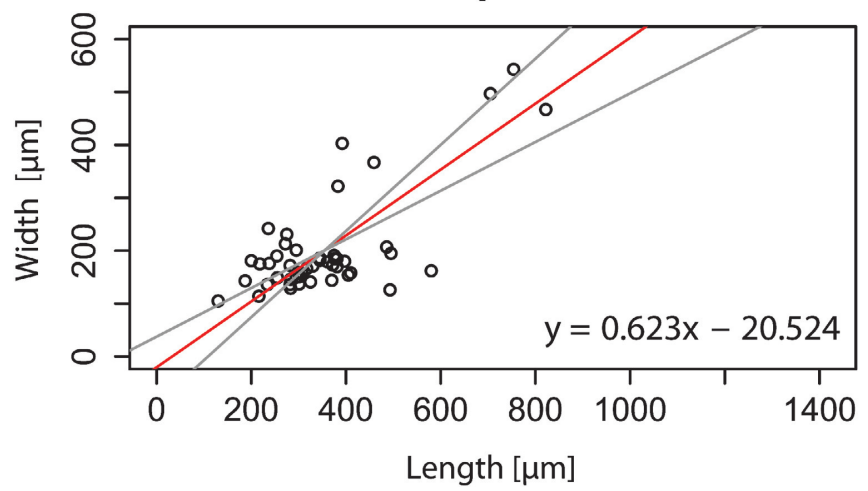

Mulde

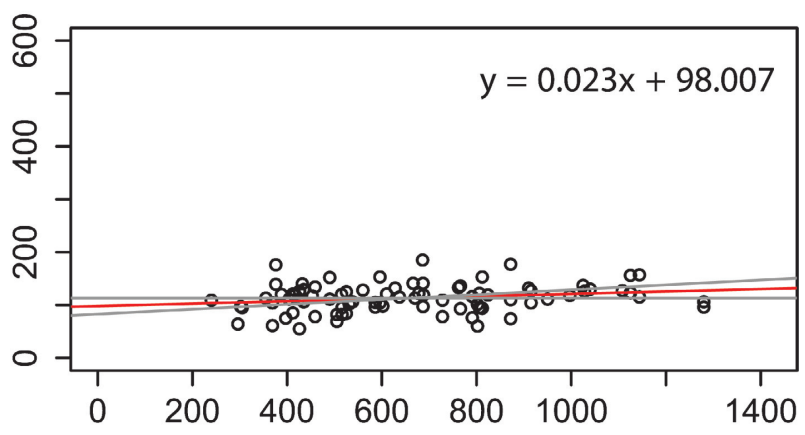

Jaani

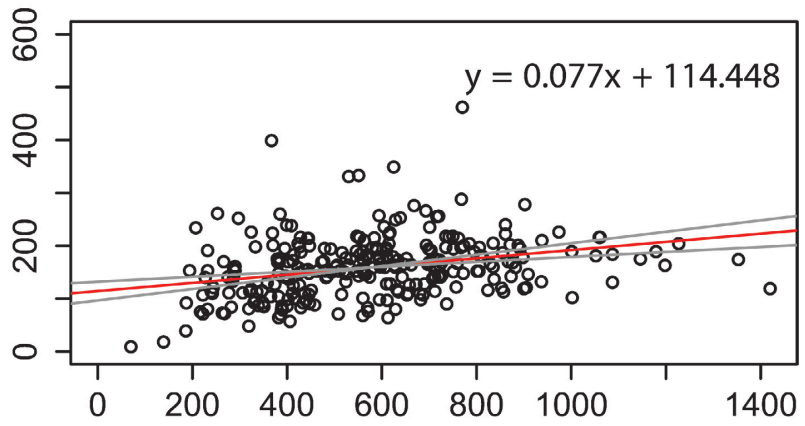

Sepise (restricted)

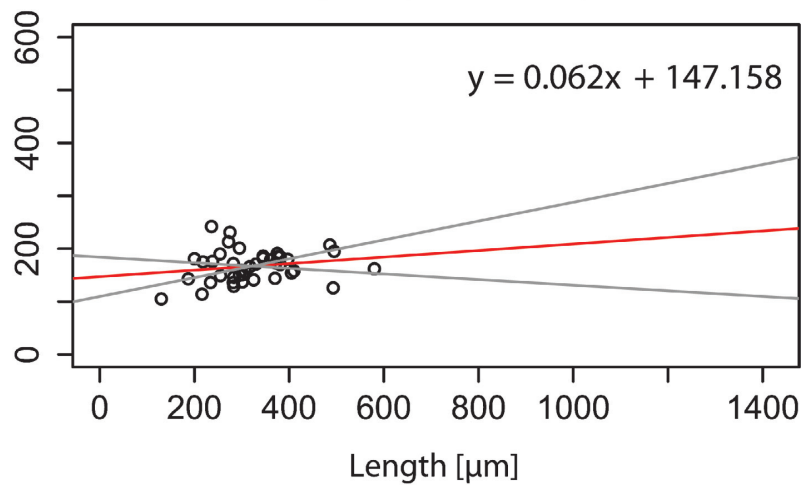

Figure 6. Major axis regression lines with $95 \%$ confidence intervals fitted to vesicle dimensions in studied Allonema populations.

Occurrence. - Reported from the Middle Devonian of Michigan and Poland, here also from the Wenlock (middle Silurian) of Saaremaa.

\section{Allonema sp. indet.}

Material. - One unidentified clast and a crinoid stem from the Jaagarahu Fm. at Sepise (Saaremaa), encrusted with Allonema sp. and $A$. aggregatum. Description is based on measurements of 41 vesicles (six largest vesicles belonging to two specimens, visible in Fig. 5 as outliers within the Sepise population are here excluded).
Description. - Sparsely branching chains formed by short (max. $322 \mu \mathrm{m}$, on average $130 \mu \mathrm{m}$ long) vesicles with the length to width ratio close to $16: 1$. In most vesicles pores are not visible. Allonema sp. co-occurs with larger and more rounded $A$. aggregatum (see above).

\section{Conclusions}

1. At least seven species of Allonema were based on insufficient samples that failed to capture intraspecific size variability. Their diagnoses were not sufficient to distinguish these species. 
2. Allonema botellus and A. moniliforme show a wider range of sizes than previously reported, but can be distinguished based on their proportions, A. botellus being at least five times more elongated than $A$. moniliforme. A. minimum falls within the range of dimensions of $A$. moniliforme and is proposed to be its junior synonym.

\section{A. moniliforme aggregatum, A. botelloides, A. fusiforme} and $A$. subfusiforme entirely overlap in their range of dimensions, differring only in vesicle shapes. Further studies are required on material representing these species to determine whether they are valid species. A. moniliforme aggregatum is similar to A. moniliforme in terms of dimensions but differs by its larger size, and is tentatively proposed here to be raised to the rank of species based on its larger size range, which distinguishes it from $A$. moniliforme.

4. Allonema is an example of a long-known, widespread organism, for which the understanding of affinity, ecology, and functional morphology is lacking. The absence of qualitative features that would allow taxonomic evaluation of its morphological variability may be overcome by quantitative shape analysis. The successful use of this approach in the present study may encourage its application to other problematica.

\section{Acknowledgements}

EJ, FH and AM acknowledge funding from the Deutsche Forschungsgemeinschaft (project no. Mu 2352/3). Financial support to OV was provided by the Palaeontological Association Research Grant, Paleontological Society Sepkoski Grant, Estonian Research Council projects ETF9064 and IUT20-34. We are grateful to M. Wilson and F. Schlagintweit for constructive reviews and language corrections, to A. Hüter, M. Hopkins and J. Spicer for help in collecting material from Värsendeojk 5, U. Toom for handling deposited material, G. Buono for discussions on the growth habit of Allonema, P. Taylor for identification of Corynotrypa sp., and C. Schulbert for help with SEM. This paper is a contribution to the International Geoscience Programme (IGCP) Project 591 - The Early to Middle Paleozoic Revolution.

\section{References}

BeŁKA, Z. 1981. The alleged algal genus Aphralysia is a foraminifer. Neues Jahrbuch für Geologie und Paläontologie, Monatshefte 5, 257-266.

Berkyová, S. \& MunneCKe, A. 2010. "Calcispheres" as source of lime mud and peloids - evidence from the Devonian of the Prague Basin, Czech Republic. Bulletin of Geosciences 85, 585-602. DOI 10.3140/bull.geosci.1206

Brett, C.E., Smrecak, T., Hubbard, K.P. \& Walker, S. 2012. Marine sclerobiofacies: encrusting and endolithic communities on shells through time and space, 129-157. In TALENT, J. (ed.) International Year of Planet Earth, Earth and Life. Springer Netherlands, Amsterdam.
Calner, M. 1999. Stratigraphy, facies development, and depositional dynamics of the Late Wenlock Fröjel Formation, Gotland, Sweden. GFF 121, 13-24. DOI 10.1080/11035899901211013

Calner, M. \& Jeppsson, L. 2003. Carbonate platform evolution and conodont stratigraphy during the middle Silurian Mulde Event, Gotland, Sweden. Geological Magazine 140, 173-203. DOI $10.1017 /$ S0016756802007070

Colbath, G.K. \& Grenfell, H.R. 1995. Review of biological affinities of Paleozoic acid-resistant, organic-walled eukaryotic algal microfossils (including "acritarchs"). Review of Palaeobotany and Palynology 86, 287-314.

DOI 10.1016/0034-6667(94)00148-D

Condra, G.E. \& Elias, M.K. 1944. Carboniferous and Permian ctenostomatous bryozoa. Geological Society of America Bulletin 55, 517-568. DOI 10.1130/GSAB-55-517

DzIK, J. 1975. The origin and early phylogeny of the cheilostomatous bryozoa. Acta Palaeontologica Polonica 20, 395-423.

Elias, M.K. 1950. Paleozoic Ptychocladia and related Foraminifera. Journal of Paleontology 24, 287-306.

ELICKI, O. 1999. Palaeoecological significance of calcimicrobial communities during ramp evolution: An example from the Lower Cambrian of Germany. Facies 41, 27-39.

DOI 10.1007/BF02537458

FLÜGEL, E. 2004. Cyanobacteria and Calcimicrobes, 408-412. In FLÜGEL, E. Microfacies of carbonate rocks. Analysis, interpretation and application. Springer, Berlin.

Frisch, K., Munnecke, A., Schulbert, C. \& Zhang, Y. 2013. Tubes or cell sheet? A 3-D reconstruction of Halysis Høeg, 1932, from the Upper Ordovician of South China. Facies 59, 113-132. DOI 10.1007/s10347-012-0329-x

GŁuchowski, E. 2005. Epibionts on upper Eifelian crinoid columnals from the Holy Cross Mountains, Poland. Acta Palaeontologica Polonica 50, 315-328.

Gradziński, M., Tyszka, J., UChMAn, A. \& JACH, R. 2004. Large microbial-foraminiferal oncoids from condensed Lower-Middle Jurassic deposits: a case study from the Tatra Mountains, Poland. Palaeogeography, Palaeoclimatology, Palaeoecology 213, 133-151. DOI 10.1016/S0031-0182(04)00380-3

HierL, F. 2014. Karbonatische Mikrofossilien aus den Svarvare-Schichten (Silur, Gotland) und ihre Bedeutung für die Rekonstruktion der Ablagerungsbedingungen. 29 pp. Bachelors thesis, Friedrich-Alexander Universität ErlangenNürnberg, Erlangen, Germany.

Jakubowicz, M., BetKa, Z. \& Berkowski, B. 2014. Frutexites encrustations on rugose corals (Middle Devonian, southern Morocco): complex growth of microbial microstromatolites. Facies 60, 631-650. DOI 10.1007/s10347-013-0381-1

Jarochowska, E. \& Munnecke, A. 2014. The Paleozoic problematica Wetheredella and Allonema are two aspects of the same organism. Facies 60, 651-662. DOI 10.1007/s10347-014-0399-z

Jarochowska, E., Tonarová, P., Munnecke, A., Ferrová, L., SKLENÁr̆, J. \& VodRÁŽKovÁ, S. 2013. An acid-free method of microfossil extraction from clay-rich lithologies using the surfactant Rewoquat. Palaeontologia Electronica 16(3), http://palaeo-electronica.org, 1-16.

Jeppsson, L., Eriksson, M.E. \& Calner, M. 2006. A latest Llandovery to latest Ludlow high-resolution biostratigraphy based on the Silurian of Gotland - a summary. GFF 128, 109-114. DOI 10.1080/11035890601282109

KiepurA, M. 1965. Devonian bryozoans of the Holy Cross Mountains, Poland. Acta Palaeontologica Polonica 10, 11-48. 
LAUFELD, S. 1974. Reference localities for palaeontology and geology in the Silurian of Gotland. Sveriges Geologiska Undersökning, ser. C 705, 1-172.

LEgENDRE, P. \& LegendRe, L. 1998. Developments in Environmental Modelling. Numerical ecology. 852 pp. Elsevier, Amsterdam.

Malinky, J.M., Wilson, M.A., Holmer, L.E. \& LardeuX, H. 2004. Tube-Shaped Incertae Sedis, 214-222. In WebBy, B.D., PARIS, F., Droser, M.L. \& Percival, I.G. (eds) The Great Ordovician Biodiversification Event. Columbia University Press, New York.

Männik, P. 2014. The Silurian System in Estonia, 123-128. In Bauert, H., Hints, O., Meidla, T. \& Männik, P. (eds) $4^{\text {th }} A n$ nual Meeting of IGCP 591 The Early to Middle Paleozoic Revolution, Estonia 10-19 June 2014. Abstracts and Field Guide. University of Tartu, Tartu.

Munnecke, A., Samtleben, C. \& Bickert, T. 2003. The Ireviken Event in the lower Silurian of Gotland, Sweden - relation to similar Palaeozoic and Proterozoic events. Palaeogeography, Palaeoclimatology, Palaeoecology 195, 99-124. DOI 10.1016/S0031-0182(03)00304-3

Munnecke, A., Samtleben, C., Servais, T. \& Vachard, D. 1999. SEM-observation of calcareous micro- and nannofossils incertae sedis from the Silurian of Gotland, Sweden: Preliminary results. Geobios 32, 307-314.

DOI 10.1016/S0016-6995(99)80044-8

Munnecke, A., Servais, T. \& Vachard, D. 2000. A new family of calcareous microfossils from the Silurian of Gotland, Sweden. Palaeontology 43, 1153-1172. DOI 10.1111/1475-4983.00165

NeSTOR, V. 1984. Zonal distribution of chitinozoans in the Wenlocki Jaani Stage of Estonia and the problem of its upper boundary, 119-127. In MÄNNIL, R.M. \& MENS, K.A. (eds) Stratigraphy of early Paleozoic sediments of the East Baltic. Valgus, Tallinn.

Nose, M., Schmid, D.U. \& Leinfelder, R.R. 2006. Significance of microbialites, calcimicrobes, and calcareous algae in reefal framework formation from the Silurian of Gotland, Sweden. Sedimentary Geology 192, 243-265. DOI 10.1016/j.sedgeo.2006.04.009

Olempska, E. \& Rakowicz, Ł. 2014. Affinities of Palaeozoic encrusting ascodictyid "pseudobryozoans". Journal of Systematic Palaeontology 12, 983-999. DOI 10.1080/14772019.2013.850118

Page, A., Wilby, P.R., Mellish, C.J.T., Williams, M. \& ZalaSIEWICZ, J.A. 2008. Dawsonia Nicholson: linguliform brachiopods, crustacean tail-pieces and a problematicum rather than graptolite ovarian vesicles. Earth and Environmental Science Transactions of the Royal Society of Edinburgh 99, 251-266. DOI 10.1017/S175569100900704X

PARIS, F. \& NõLVAK, J. 1999. Biological interpretation and paleobiodiversity of a cryptic fossil group: The "chitinozoan animal". Geobios 32, 315-324. DOI 10.1016/S0016-6995(99)80045-X

PRATT, B.R. 1984. Epiphyton and Renalcis; diagenetic microfossils from calcification of coccoid blue-green algae. Journal of Sedimentary Research 54, 948-971.

R CORE TEAM 2015. R: A language and environment for statistical computing. R Foundation for Statistical Computing, Vienna.

Raukas, A. \& Teedumäe, A. 1997. Geology and Mineral Resources of Estonia. 436 pp. Estonian Academy Publishers, Tallinn.

Riding, R. 1991. Calcified Cyanobacteria, 55-87. In Riding, R. (ed.) Calcareous Algae and Stromatolites. Springer, Berlin.
Riding, R. \& SojA, C.M. 1993. Silurian calcareous algae, cyanobacteria, and microproblematica from the Alexander Terrane, Alaska. Journal of Paleontology 67, 710-728.

Simonsen, A.H. \& CufFey, R.J. 1980. The University of Kansas Paleontological Contributions. Fenestrate, pinnate, and ctenostome bryozoans and asociated barnacle borings in the Wreford Megacyclothem (Lower Permian) of Kansas, Oklahoma, and Nebraska. 38 pp. The Paleontological Institute, The University of Kansas.

SpJeldnaes, N. 1984. Epifauna as a tool in autecological analysis of Silurian brachiopods. Special Papers in Palaeontology 32, 225-235.

Szulczewski, M. 1995. Depositional evolution of the Holly Cross Mts. (Poland) in the Devonian and Carboniferous - a review. Geological Quarterly 39, 471-488.

TAYlor, P.D. \& WiLson, M.A. 2003. Palaeoecology and evolution of marine hard substrate communities. Earth-Science Reviews 62, 1-103. DOI 10.1016/S0012-8252(02)00131-9

UlRICH, E.O. \& BASSLER, R.S. 1904. A revision of the Paleozoic Bryozoa, Part I: On genera and species of Ctenostomata. Smithsonian Miscellaneous Collections 45, 256-294.

Vachard, D., Hauser, M., Martini, R., Zaninetti, L., Matter, A. \& Peters, T. 2001. New algae and problematica of algal affinity from the Permian of the Aseelah Unit of the Batain Plain (East Oman). Geobios 34, 375-404. DOI 10.1016/S0016-6995(01)80003-6

VINE, G.R. 1884. IX. - Notes on species of Ascodictyon and Rhopalonaria from the Wenlock Shales. Annals and Magazine of Natural History 14, 77-89.

DOI 10.1080/00222938409459772

VINE, G.R. 1887. Notes on the classifications of cyclostomatous Polyzoa; old and new. Proceedings of the Yorkshire Geological and Polytechnic Society 9, 346-362.

DOI 10.1144/pygs.9.3.346

VinN, O. \& WiLSON, M.A. 2013. Silurian cornulitids of Estonia (Baltica). Carnets de Géologie 357-368.

DOI 10.4267/2042/53034

Vinn, O. \& Zatoń, M. 2012. Phenetic phylogenetics of tentaculitoids - extinct, problematic calcareous tube-forming organisms. GFF 134, 145-156. DOI 10.1080/11035897.2012.669788

Warton, D.I., Duursma, R.A., Falster, D.S. \& Taskinen, S. 2012. Smatr 3 - an R package for estimation and inference about allometric lines. Methods in Ecology and Evolution 3, 257-259. DOI 10.1111/j.2041-210X.2011.00153.x

WestFalL, P.H. \& Young, S.S. 1993. Resampling-based multiple testing: Examples and methods for p-value adjustment. 360 pp. John Wiley \& Sons, New York.

Whiteaves, J.F. 1891. The Fossils of the Devonian Rocks of the Mackenzie River Basin. Contributions to Canadian Paleontology 1, 197-253.

Wilson, M.A. \& TAYLOR, P.D. 2001. "Pseudobryozoans" and the problem of encruster diversity in the Paleozoic. PaleoBios 21, 134-135.

Wilson, M.A. \& TAYLOR, P.D. 2014. The morphology and affinities of Allonema and Ascodictyon, two abundant Palaeozoic encrusters commonly misattributed to the ctenostome bryozoans. Studi Trentini di Scienze Naturali 94, 259-266.

Wood, A. 1948. "Sphaerocodium," a misinterpreted fossil from the Wenlock limestone. Proceedings of the Geologists' Association 59(1), 9-22, IN2-IN5.

DOI 10.1016/S0016-7878(48)80027-1 